\title{
Pryzmaty postrzegania: estetyka, ideologia, interpretacja w sztukach pięknych
}

\author{
Katarzyna Stanny
}

(Akademia Sztuk Pięknych w Warszawie)

Jak podaje definicja słownikowa, w rozumieniu najprostszym i niemetaforyczym soczewka optyczna jest to:

\ bryła z przezroczystego materiału o współczynniku załamania innym niż otaczającego ośrodka, ograniczona (przynajmniej z jednej strony) powierzchniami sferycznymi; stanowi podstawowy element układów optycznych. Powierzchnie ograniczające (tzw. powierzchnie łamiące) są najczęściej kuliste, ze względu na łatwość ich wykonania; niekiedy, gdy szczególnie ważne jest uniknięcie niektórych aberracji, mogą mieć kształt cylindryczny lub paraboliczny. Rozróżnia się dwa zasadnicze typy soczewki: zbierające $[\ldots]$ i rozpraszające $[\ldots]^{\mathrm{I}}$.

Tyle z suchej, naukowej dziedziny optyki. Definicję tę można byłoby jeszcze rozbudowywać o kolejne informacje i wzory naukowe dotyczące tego zagadnienia, tylko że temat $W$ soczewce. Wybrane aspekty wizualności w XIX wieku ujmuje o wiele szerzej istotę widzenia. Widzenia także poprzez osobisty pryzmat indywidualnej „soczewki”, którą każdy ma wbudowaną w swoje własne „wyposażenie”. Kiedy zaproponowałam ten temat studentom prowadzonej przeze mnie Pracowni Projektowania Intermedialnego Wydziału Sztuki Mediów warszawskiej ASP, początkowo byli onieśmieleni faktem, że ich myślenie o temacie, po przejściu przez fazę akceptacji teoretycznej, ma się następnie w pewnym sensie zatrzymać w oku, w obiektywie czy na płaszczyźnie soczewki aparatu fotograficznego. Jak się okazało, zadany temat skłonił osoby zajmujące się głównie fotografią do zupełnie

1 Hasło „Soczewka”, w: Wielka Encyklopedia Powszechna PWN, t.10, Warszawa 1967, s. 643-644. 
innego spojrzenia na sprzęt, jakim posługują się od wielu lat. Ich „autofocus” często nie ma włączonej autorefleksji. Dzięki pracy nad tym tematem zyskali pewien dodatkowy filtr artystycznego myślenia o tym, co widzą w obiektywie sprzętu, będącego nie tylko metaforycznym, ale także dosłownym przejściem ze świata wyobraźni i myślenia o projekcie do świata twórczej realizacji.

\Wszelka komunikacja fotograficzna, jak się wydaje, zachodzi w ramach czegoś w rodzaju podwójnego mitu. A więc istnieje mit „symbolistyczny” i mit „realistyczny”. Mylącą, lecz bardzo popularną formą tej opozycji jest „fotografia artystyczna” przeciwstawiona „fotografii dokumentalnej”. Każda fotografia - w dowolnym momencie jej odczytywania - w jakimkolwiek kontekście, zawsze ciąży ku jednemu z tych biegunów znaczenia. Opozycje między nimi są następujące: fotograf jako wizjoner i fotograf jako świadek, fotografia jako ekspresja i fotografia jako reportaż $\dot{z}^{2}$

"Nowe media” to pojęcie bardzo szerokie, dotyczące wielu form wypowiedzi za pomocą narzędzi nowocześniejszych niż kartka i ołówek. Artystyczna opowieść o soczewce snuta za pomocą jedynie tej techniki byłaby dość trudna. Bez względu jednak na jej zastosowanie w sztuce nowoczesnej, w każdym projekcie przede wszystkim powinien liczyć się pomysł i warsztat, ponieważ sztuka współczesna ma przed sobą inne zadania, niż miała we wspomnianym w tytule wieku XIX. Dobrze, jeśli mądrze komentuje ona współczesne problemy czy wyraża stosunek artysty wobec jakiegoś zjawiska; wspaniale, jeśli jest trafnym komentarzem prezentującym pewien światopogląd. Natomiast coraz rzadziej jest to działanie, które służy potencjalnemu odbiorcy do zaspokojenia jego estetycznych tęsknot obcowania z pięknem. Zarówno w sztukach pięknych, jak i we współczesnej literaturze wiele jest ekstrawagancji, szokowania do granic, które już chyba dawno zostały przekroczone. Piękno przestało być wartością. Jego przejawy można spotkać jeszcze w sztuce użytkowej, mam tu na myśli szeroko pojęty „design”, tutaj jednak też nie może ono być wolne od ram, które stawiają mu wymogi użytkowości. Piękno, tak jak i dobro, obecnie nie są wartymi pierwszych stron „newsami”, bo dobry „news” to taki, który szokuje, zniesmacza albo przeraża - to się sprzedaje. Podobnie jest ze sztuką współczesną. Warto dodać, że o tym, czy dany eksponat jest dziełem sztuki, czy nie, decyduje przede wszystkim miejsce jego prezentacji oraz kurator wystawy. Galeria albo muzeum nadają kontekst pokazywanemu obiektowi, a interpretacje takich zjawisk są wielowymiarowe.

2 A. Sekula, Spoteczne użycia fotografi, tłum. K. Pijarski, Warszawa 2010, s. 35. 
Należy pamiętać, że wyrażanie się poprzez tradycyjne techniki (płótno, farba, pędzel) nie oznacza zawsze tradycyjnego podejścia do malarstwa. Akademicy zostali, jak wiadomo, wyparci przez impresjonistów, a następne dekady proponowały tak wiele różnych od siebie ścieżek malarskich, że trudno jest mówić o tym, czym w ogóle jest np. współczesne malarstwo. Nie podjęłabym się zdefiniowania tego zjawiska. Trudno też na bieżąco oceniać, bo dopiero historia sztuki filtruje i pozostawia to, co wartościowe.

Wracając do tematu aspektów wizualności w sztukach, będących wówczas jeszcze pięknymi, w wieku XIX, należy z pewnością zacząć od wspomnianych wcześniej impresjonistów. Osiem paryskich wystaw prezentowanych w latach I874-I886 spowodowało zerwanie $\mathrm{z}$ obowiązującym wówczas akademizmem i w pewnym sensie powoli zaczęło doprowadzać twórców do abstrakcji i całkowitego wyjścia poza ramy nie tylko oprawionego obrazu, ale przede wszystkim przyjętych przez lata w malarstwie zasad. Założona jeszcze za panowania Ludwika XIV paryska Académie Royale de Peinture et de Sculpture przywiązywała dużą wagę do szkolenia umiejętności rysunkowych wedle ścisłych zasad doktryny wyidealizowanego piękna, na podstawie rysunkowego kopiowania modeli gipsowych starożytnych rzeźb. Kolor traktowany był wówczas jako pewien rodzaj światła uzyskiwanego za pomocą gamy brązowych i ciepłych laserunków, „żywe” barwy były zakazane, uznane jedynie za składniki malarskie niezbędne do stworzenie zasadniczej palety, oddającej dość monochromatyczne widzenie odwzorowywanej rzeczywistości.

Za symboliczny początek nowego widzenia świata w malarstwie uznaje się I wystawę grupy artystów zorganizowaną w atelier fotograficznym Nadara w I874 roku, a także obraz Claude'a Moneta Impresja, wschód stońca. Ironicznie nadana jego zwolennikom przez krytyka sztuki i dziennikarza Louisa Leroy'a nazwa „impresjoniści” od tamtego czasu weszła na stałe do obowiązującego słownika historii sztuki.

Skąd zatem taka nagła zmiana sposobu widzenia rzeczywistości przez grupe francuskich malarzy? Charakterystyczną cechą zarówno malarstwa, jak i impresjonistycznej rzeźby było dążenie do oddania zmysłowych, ulotnych momentów i „schwytania uciekających chwil”, które (jak się dziś okazuje) w porównaniu ze współczesnym pędem cywilizacyjnym płynęły wówczas całkiem spokojnie.

Niewątpliwie jednym z czynników mających wpływ na zmianę w ówczesnym malarstwie był rozwój techniczny i naukowy. Postęp w optyce przyczynił się do zwiększenia wiedzy na temat fizycznej natury światła, które jest w istocie mieszaniną wszystkich barw tęczy, co z kolei stało się przełomem w fizycznej teorii barwy. Po raz pierwszy malarstwo i sztuka spotkały się na polu fizyki, będącej nauką ścisłą. Pod względem rewolucji, jak wiadomo, Francja ma bogate tradycje. Pracujący w królewskiej manufakturze gobelinów - chemik - Michel Cheverul, 
sformułował w roku I839 prawo równoczesnego kontrastu. Jego założenia polegają na tym, że:

》 oko widząc jakąś barwę zawsze wytwarza barwę przeciwstawną (dopełniającą), a konsekwencją tego prawa jest stwierdzenie, że położone obok siebie na obrazie dwie dowolne barwy oko widzi jako wzajemnie maksymalnie zróżnicowane. Inna konsekwencja jest wskazówką praktyczną: jeśli na obrazie znajdują się obok siebie dwie barwy przeciwstawne, to będą one różnić się bardziej niż wszelkie inne zestawienia dwu barw. Impresjoniści korzystali jedynie z siedmiu podstawowych barw światła białego i jako pierwsi mieszali je dopiero na płótnie, a nie jak ich poprzednicy na palecie ${ }^{3}$.

Kolejnym ważnym krokiem, poczynionym przez dziewiętnastowiecznych malarzy, był jeszcze bliższy naukowej teorii widzenia rozwój malarstwa pointylistycznego - kierunku z pogranicza optyki, nauki i wrażliwości widzenia otaczającej rzeczywistości. Osobiście jest to dla mnie malarstwo trudne do zdefiniowania, gdyż dalekie od spontanicznego gestu i pewnej lekkości interpretowania rzeczywistości. Jak piszą autorzy Leksykonu malarstwa od $A$ do $Z$, „pointylizm” jest to

\ Technika malarska stosowana przez neoimpresjonistów, polegająca na nakładaniu koloru drobnymi, regularnie rozmieszczonymi plamkami tworzącymi oddzielne, nie łączące się ze sobą punkty. Wykorzystywano w niej barwy wyłącznie podstawowe. Powierzchnia obrazu pointylistycznego składa się zatem z maleńkich kolorowych drobinek, które zlewając się w oku widza, dają wrażenie jednolitej plamy barwnej i bogactwa tonacji walorowych ${ }^{4}$.

Malarska paleta poszczególnych barw zostaje więc przez artystów tego nurtu przeniesiona na płótno z precyzją subtelnych, ale konsekwentnych dotknięć pędzla.

Niezaprzeczalnie duży wpływ na rozwój impresjonizmu miało wynalezienie i upowszechnienie się fotografii. Malarstwo nie musiało już nadążać za odwzorowywaniem rzeczywistości, mogło stać się niepodległą dziedziną, wolną

3 Zob. www.szkolnictwo.pl (stan z dn. 22 lutego 2015 r.).

4 Hasło „Pointylizm”, w: Leksykon Malarstwa od A do Z, tłum. M. Czarzasty i A. Gałęzowski, red. nauk i nowe teksty P. Szubert i P. Trzeciak, Warszawa 1992, s. 569. 
i skrępowaną jedynie koniecznością wpisania się w nowo obowiązujące zasady mieszania barw.

Jak stwierdzają autorzy cytowanego wcześniej leksykonu: „Doniosłym osiągnięciem impresjonistów było także swoiste kadrowanie przedstawionego motywu, sugerujące przypadkowość ujęcia. Służyły temu ostre skróty perspektywiczne, asymetria i tzw. ucinanie motywu"s, co wywoływało poruszenie na artystycznych salonach. Impresjonizm poprzez nowe widzenie rzeczywistości i jej interpretację, miał duży wpływ na większość kierunków sztuki, które po nim nastąiły, zarówno w muzyce czy literaturze, jak i filozofii.

Widzenie impresjonistów to jedynie pewna metoda malarska interpretacji świata. Czym innym natomiast są wady wzroku, jakie po latach odkrywają badacze na podstawie analizowania twórczości poszczególnych malarzy. Są to wady będące często wyznacznikiem stylu i powodujące, że dany artysta z tego właśnie powodu zapisał się w historii sztuki. Najbardziej chyba znanym przykładem jest mistrz włoskiego manieryzmu El Greco (I54I-I6I4), tworzący pod silnym wpływem Tycjana i Tintoretta, tak widocznym w jego malarstwie. Tworzył we Włoszech i Hiszpanii, zajmując się głównie tematyką religijną. Jego deformacje postaci zdaniem historyków sztuki nie są jedynie wyrazem artystycznej interpretacji i uduchowienia wizji malarskiej, ale także wynikiem wady wzroku, jaką jest astygmatyzm. Wady wzroku mogą być w pewnym sensie zaletami, pomocą dla tworzenia obrazów, nie tylko malarskich, ale także fotograficznych. Temat ten szerzej poruszyła studentka Paulina Stawska, realizując pod moim kierunkiem pracę licencjacką zatytułowaną Tak to widzę. W publikowanym poniżej fragmencie opisuje wizję swojej interpretacji poszczególnych wad wzroku, jakie występują w okulistyce. $Z$ „deficytu” odbioru rzeczywistości autorka uczyniła w ten sposób metodę na stworzenie ciekawych obrazów - fotografii z pogranicza grafiki użytkowej.

Opisywane dotychczas przeze mnie aspekty widzenia rzeczywistości w sztuce dotyczą jedynie fizycznego przełożenia artystycznej wizji czy projektu na płótno lub obraz fotograficzny. Niewątpliwie ważnym aspektem jest także sposób postrzegania świata przez artystów i ich interpretację rzeczywistości, przeniesioną na pole sztuk pięknych. W tym kontekście należy pamiętać także o tym, że sposób widzenia zjawisk zmienia się także na przestrzeni epok, wraz z upływem lat i zmianami obyczajowymi zachodzącymi w otaczającej nas rzeczywistości.

Punkt widzenia danego zjawiska czy też odbierania go poprzez pewien pryzmat, to zazwyczaj zarazem punkt wyjścia kolejnej dziedziny sztuk pięknych, być może nieco mniej docenianej, czyli satyry. Najwybitniejszym przedstawicielem

5 Hasło: „Impresjonizm”, w: ibidem, s. 331. 
rysunkowej satyry politycznej jest niewątpliwie francuski rysownik, malarz i rzeźbiarz Honoré Daumier (I808-1879). Był on jednym ze znakomitszych przedstawicieli realizmu XIX wieku. Realistyczna forma przedstawienia, w jakiej tworzył, służyła jedynie jako narzędzie artystyczne dla ukazania humorystycznego sposobu widzenia otaczającej go rzeczywistości politycznej i społecznej ${ }^{6}$.

Rzeźbiarskie popiersia Daumiera stanowią połączenie studium anatomicznego z wyostrzonym spojrzeniem na wnętrze portretowanej osoby. Fizjonomia oraz charakter uzupełniają się, bez dużej szkody dla bohatera. Poruszane w rysunkach prasowych wątki polityczne, ubieranie alegorii krajów w kostiumy zwierząt, komentują ostro polityczną rzeczywistość przy zachowaniu pięknej formy rysunkowej i poprawności ilustracyjnej.

Jego karykaturalne portrety, tak rzeźbiarskie, jak i rysunkowe, są przykładem równoległego impresjonistom, ale zupełnie innego widzenia ówczesnej Francji, przedstawionej w krzywym zwierciadle satyrycznego pryzmatu. Czy jednak już wówczas satyryczny rysunek prasowy przekraczał przyjęte granice obowiązujących wartości, czy balansował dopiero na granicy przekroczonej przez nazistowska prasę niemiecką w latach trzydziestych XX wieku? Wydaje się, że obyczajowość ujęta w ramy dobrego smaku i kultury XIX wieku nie pozwalała jeszcze wówczas na przekroczenie granicy w tak drastyczny sposób, jak miało to miejsce w pierwszej połowie XX wieku. Polityczny punkt widzenia dochodzącej do władzy NSDAP z pewnością przyczynił się do sposobu postrzegania niemieckiego społeczeństwa przed wybuchem II wojny światowej, a nawet nieco wcześniej. Dla Europy Środkowej istotnym punktem zwrotnym było powstanie antysemityzmu politycznego w krajach niemieckich. Agitacji antysemickiej towarzyszyła napastliwa ilustracja. Na ziemiach Cesarstwa Austro-Węgierskiego od I86I r. wychodził satyryczny periodyk „Kikeriki” (właśc. „Kikeriki! Wiener humoristisches Volksblatt”). Pielęgnowane przez stulecia uprzedzenia antyżydowskie i nowoczesne stereotypy antysemickie znalazły swój ilustracyjny komentarz we francuskich pismach satyrycznych, m.in.: „Le Mirliton”, „La Caricature” czy „Le Canard Sauvage”. Rysunki paryskich artystów publikowane były na łamach prasy francuskojęzycznej, m.in.: w Belgii, Szwajcarii, a także w krajach romańskich,

6 Daumier rozpoczął karierę na łamach prasy zaraz po Rewolucji 1830 roku, kiedy jako rysownik i litograf został zatrudniony przez Charlesa Philipona w tygodniku „La Caricature”, a od 1863 roku w piśmie „Charivari”. Dał się wówczas poznać jako karykaturzysta polityczny o ostrej nie tylko rysunkowo, ale także merytorycznie kresce i jako niezastąpiony badacz obyczajów swojej epoki. Za życia artysty najważniejsze miejsce zajmowało jego dzieło litograficzne - cykle satyryczne o charakterze obyczajowym: Robert Macaire (1836-38), Typy paryskie (1839-42), Z historii starożytnej (1842), Bas-Bleus (1844), Obyczaje maṫ̇enskie (1838-39), Ludzie palestry (1845-49), Profesorowie i uczniowie (1845-46) oraz politycznym: Przedstawiciele przedstawieni, Sielanki parlamentarne, Fizjonomie Zgromadzenia Narodowego, Aktualności (zob. hasło „Daumier Honoré”, w: ibidem, s. 161). 
przede wszystkim we Włoszech, Rumunii i Hiszpanii. Natomiast w Europie Wschodniej zjadliwe wizerunki żydowskie rozpowszechniły się wraz z rozwojem prasy masowej, co miało miejsce po Rewolucji 1905 r. ${ }^{7}$.

Po pierwszej wojnie światowej zaczęły wychodzić w Niemczech najbardziej agresywne satyryczne pisma antysemickie, np. „Der Stürmer”Juliusa Streichera (wydawany od 1923 r.). Polska karykatura antysemicka dołączyła do tego globalnego rynku etnicznej nienawiści pod koniec pierwszej dekady XX w., kształtując punkt widzenia społecznego przez tak istotne medium, jakim od zawsze była i jest prasa. Poprzez brutalną formę przekazu wizualnego popularyzowała ona wizerunek Żyda jako intruza, podżegając w ten sposób do nienawiści oraz rozpowszechniając antysemityzm. Soczewka, przez którą ówcześni rysownicy widzieli Polskę, stała się narzędziem siejącym społeczną nienawiść, często wyrażającą aprobatę dla antyżydowskich działań hitlerowskich Niemiec i faszystowskich Włoch. Wyrażający się w rysunkach satyrycznych aspekt kształtowania światopoglądu wpływał na nastroje i poglądy na „kwestię żydowską”.

W okresie międzywojennym rysunki takie publikowane były na łamach m.in.: „Kuriera Poznańskiego”, „Dziennika Bydgoskiego”, „ABC - Nowin Codziennych”, „Wieczoru Warszawskiego”, „Podbipięty”, „Prosto z mostu”, „Szczutka”, „Szopki”, „Muchy”, „Żółtej Muchy”, „Szarży”, „Pokrzyw”, „Szabes-Kuriera”. Autorami rysunków widzącymi w deformującej soczewce antysemicki obraz otoczenia, byli niestety często uznani i docenieni rysownicy profesjonalni, tacy jak m.in.: Jerzy Zaruba, Kamil Mackiewicz, Włodzimierz Bartoszewicz, Włodzimierz Łukasik, Jerzy Srokowski, Kazimierz Grus i Maja Berezowska ${ }^{8}$.

W tym wypadku należałoby zadać sobie pytanie: czy rzeczywiście wolność prasy mogącej w tak szerokim spektrum kształtować światopogląd, powinna być wolna od wszelkiej kontroli? Czy język wyższości, pogardy i nienawiści, wzmacniający tragiczne w skutkach uprzedzenia i stereotypy rasowe powinien być językiem całkowicie swobodnym i bez ograniczeń dopuszczonym do mediów, mających ogromną siłę społecznego odbioru, kształtowania się postaw i punktów widzenia na prezentowane zjawiska?

W tym wypadku wolność mediów jest całkowicie poza kontrolą, prowadząc do skrajnie antagonizujących ideologii, które także współcześnie zyskują na sile. Przykładem niech będą wielokrotne profanacje wartości religijnych, dokonywane pod hasłem wolności wypowiedzi w sztuce. Granice wyrażania własnego świato-

7 Zob. „Obcy i niemili”. Antysemickie rysunki z prasy polskiej 1919-1939 / "Alien and unpleasant”. Antisemitic drawings from the Polish press, katalog wystawy w Żydowskim Instytucie Historycznym im. Emanuela Ringelbluma, red. M. Budkowska, tłum. B. Smerin, Warszawa 2013. 
poglądu nie powinny naruszać norm przyjętych przez inne religie czy tradycje. W tym miejscu nasuwa się - jakże aktualna - niedawna dyskusja w mediach, dotycząca francuskiego tygodnika „Charlie Hebdo”, związana z zamachem na jego redakcję 7 stycznia 2015 roku. Karykatury, polemiki i żarty publikowane na jego łamach kształtowały światopogląd, były soczewką widzenia problemów, różnic i antagonizmów występujących we współczesnej Francji i jej społeczeństwie, naruszając w sposób jednoznaczny wartości religijne, wyznawane przez krytykowane na jego łamach mniejszości. Karą za (wydawałoby się) niewinną, rysunkową zniewagę był atak terrorystyczny, w wyniku którego zginęła cała redakcja tygodnika. W imię obrony wizerunku swojego Boga - Allacha, terroryści wymierzyli „boskie wyroki”. Soczewka, przez którą patrzyli na problem wyznawanej przez siebie religijnej ideologii, okazała się nie być kolorowym kalejdoskopem żartobliwych rysunków, zamieniając się w perspektywę celownika na lufie kałasznikowa, skutkując krwią i łzami pokrzywdzonych rodzin i Francji pogrążonej w żałobie.

Na tym przykładzie widać, że skala pryzmatu widzenia, także w sztuce i jej nurtach, może być nieskończenie szeroka, a jego nie zawsze kolorowe promienie prowadzić mogą aż do wieczności...

\section{Bibliografia:}

Leksykon Malarstwa od $A$ do Z, tłum. M. Czarzasty i A. Gałęzowski, red. naukowa i nowe teksty P. Szubert i P. Trzeciak, Warszawa 1992;

"Obcy i niemili". Antysemickie rysunki z prasy polskiej 1919-1939 / "Alien and unpleasant”. Antisemitic drawings from the Polish press, katalog wystawy w Żydowskim Instytucie Historycznym im. Emanuela Ringelbluma, red. M. Budkowska, tłum. B. Smerin, Warszawa 2013;

Sekula A., Spoteczne użycia fotografii, tłum. K. Pijarski, Warszawa 2010;

www.szkolnictwo.pl (stan z dn. 22 lutego 2015 r.).

SŁowa KLUcze: wizualność, piękno, rzeczywistość, punkt widzenia, interpretacja

\section{Katarzyna Stanny}

Prisms of Perception: Aesthetics, Ideology, Interpretation in Fine ArTs

Analising a subject $W$ soczewce. Wybrane aspekty wizualności w XIX wieku ['In the eyelens: chosen aspects of visuality in the nineteenth century'] from a perspective of fine arts, the article addresses a few various threads of interpretation of this phenomenon. One of them belongs to painting and technical side of impressionists, 
the other - eye defects related to ophthalmology and medicine, having an impact on translation of the real world into an artistic image, while another - a way of looking through the prism of ideological perceptions and interpretations in art. Despite their differences, each is equally important. It can be infinitely many interpretations of reality, which is why it is so difficult to talk about objectivity of looking through individual lens that each of us has from the moment of birth.

KEY wORDs: visibility, beauty, reality, point of view, interpretation 